DOI: $10.25178 /$ nit.2019.1.7

\title{
Визуально-текстовая агиография в настенных листах современных старообрядцев часовенного согласия"
}

\author{
Александр В. Костров \\ Иркутский государственный университет, Российская Федерация,
}

Тамара Б. Моррис

Орегонский университет, США
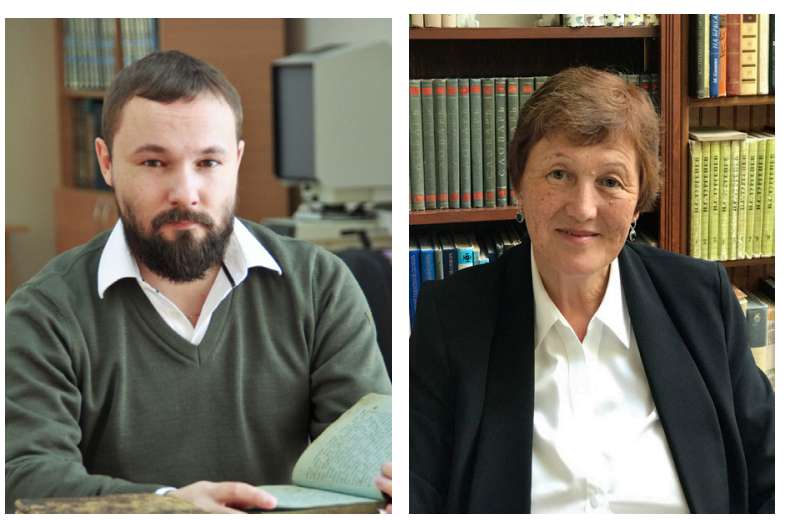

В последнее время у некоторых старообрядческих согласий происходит ренессанс настенного листа, который в новых условиях бытования принимает разные специфические формы. Особого внимания заслуживает развитие этого феномена у старообрядцев часовенного согласия, проживающих в Енисейской Сибири и поддерживающих связи со своими одноверцами из других регионов страны и мира. Нарастающие и нередко разрушающие традицию связи с внешним обществом они стремятся компенсировать за счёт культивирования старых и создания новых жанров конфессионального искусства. К подобной новации можно отнести реалистичные портреты духовных лидеров, нередко выступающие в комплексе с духовными стихами. Подобные произведения по признаку их происхождения, структуры, содержания и бытования можно отнести к визуально-текстовой агиографии современных часовенных старообрядиев. В качестве источниковой базы исследования использовались полевые материалы авторов 2016-2018 г2., собранные в России (на территории Восточной Сибири - Тувы, Красноярского края, Иркутской области) и США (Орегон, Миннесота), где находятся общины этого согласия. Использовались изобразительные, письменные и устные источники.

Анализировались портреты иноков и игуменов таежных скитов - отиов Григория, Гурия, Тимофея, Лаврентия и Михаила. Особый интерес при этом представляет портрет отца Михаила и содержательный мемориальный стих, посвященный этому известному деятелю часовенного согласия, полный текст которого приводится. Обогащение портретного образа текстом ключевых фраз и особенно мемориальных духовных стихов превращает его в информативное и драматическое визуально-текстовое агиографическое произведение. Визуально-текстовая агиография современных часовенных старообрядцев становится важнейшей частью реконструкции, сохранения и трансляции исторической памяти их согласия-церкви.

Ключевые слова: старообрядчество; часовенное согласие; Енисей; Приенисенье; Восточная Сибирь; Южная Сибирь; духовный стих; визуально-текстовая агиография

“Выполнено при поддержке РФФИ (проект «Енисейский меридиан» старообрядчества: сохранение и развитие традиции в условиях таежных скитов и монастырей», грант № 18-09-00723A).

\section{Для цитирования:}

Костров А. В., Моррис Т. Б. Визуально-текстовая агиография в настенных листах современных старообрядцев часовенного согласия [Электронный ресурс]// Новые исследования Тувы. 2019, № 1. URL: https://nit.tuva.asia/nit/article/view/831 (дата обращения: дд.мм.гг.). DOI: 10.25178/nit.2019.1.7

Костров Александр Валерьевич - доктор исторических наук, доцент, профессор кафедры мировой истории и международных отношений Иркутского государственного университета. Адрес: 664003, Россия, г. Иркутск, ул. К. Маркса, д. 1. Тел.: +7 (914) 929-40-50. Эл. адрес: a_kostrov@mail.ru ORCID: 0000-0001-5274-5424

Моррис Тамара Балдановна - доктор филологических наук, почетный профессор факультета русистики, восточноевропейских и евразийских исследований Орегонского университета. Адрес: 175 Prince Lucien Campbell 5281 University of Oregon, Eugene, OR 97403-5281, USA. Тел.: +1 (541) 346-40-78. Эл. адрес: yumsunova54@gmail.com ORCID: 0000-00020983-5587

Kostrov Aleksandr Valerevich, Doctor of History, Professor in Chair of World History and International Relations, Irkutsk State University. Postal address: 1 K. Marks St., Irkutsk, 664003, Russia. Tel.: +7 (914) 929-40-50. E-mail: a_kostrov@mail.ru

Morris Tamara Baldanovna, Doctor of Philology, Courtesy Professor, Faculty of Russian, East European, and Eurasian Studies, University of Oregon. Postal address: 175 Prince Lucien Campbell 5281 University of Oregon, Eugene, OR 97403-5281, USA. Tel.: +1 (541) 346-4078. E-mail: yumsunova54@gmail.com 


\title{
Visuality and Textuality in Hagiographic Posters of Old Believers of the Chasovennye ("chapel-going") Denomination"
}

\author{
Aleksandr V. Kostrov \\ Irkutsk State University, Russian Federation, \\ Tamara B. Morris \\ University of Oregon, USA
}

Modern-day Old Believers of the 'chapel-going" denomination (chasovennye) strive to preserve their doctrines and culture, and yet they are willing to adapt them in order to meet the needs of their communities in our constantly developing and changing world. Old Believers seek to compensate for the increasing and often destructive influence of the outer world on their traditions by simultaneously cultivating existing genres and creating new genres of their confessional art.

The realistic representation of spiritual leaders in portraits, which are often accompanied by spiritual verses can be attributed to such an innovation. This composition can be attributed as visual-texts hagiography.

The field collections made by the authors in 2016-2018 in Russia (on the territory of Eastern Siberia - Tuva, Krasnoyarsk Krai, Irkutsk oblast) and in the USA (Oregon, Minnesota), where the Chasovennye communities are found, were used as sources for this study - including images, written and oral sources.

We have examined a number of portraits of monks and hegumenons of taiga sketes, especially those of Frs. Grigorii, Gurii, Timofei, Lavrentii and Mikhail. Of particular interest is the portrait of Fr. Mikhael and the accompanying informative memorial verse, dedicated to this famous religious figure of this denomination (full text provided in the article).

The additional meaning given to the image by the memorial text turns it into an informative and highly dramatic hagiographic unity of the visual and the textual. This combined type of hagiography, common among contemporary Old Believers of the Chasovennye denomination, has become an integral part of reconstruction, saving and broadcasting the collective historical memory of their church community.

Keywords: Old Believers; Chasovennye; Dubches; portraits; spiritual verses; visual/textual hagiography; Yenisei; Yenisei region; Eastern Siberia; Southern Siberia

"Supported by RFBR, project no18-09-00723A "The Yenisei Meridian" of the old believers: the preservation and development of traditions in a taiga monasteries and villages.

\section{For citation:}

Kostrov A. V., Morris T. B. Visuality and Textuality in Hagiographic Posters of Old Believers of the Chasovennye ("chapel-going") Denomination. The New Research of Tuva, 2019, no. 1 [on-line] Available at: https://nit.tuva.asia/nit/article/view/831 (accessed: ... ). DOI: 10.25178/nit.2019.1.7

\section{Введение}

Визуальный ряд старообрядческой культуры включает в себя разные объекты изобразительного искусства. Особое место в нем занимают икона и книжная иллюстрация, относящиеся к канонам визуальной трансляции основ религиозной доктрины. Вместе с тем в старообрядческой среде получил развитие и распространение жанр лубочного настенного листа, который в том числе выполняет функцию назидания и толкования доктринальных смыслов применительно к церковным, общественным, семейным и индивидуальным бытовым ситуациям. И если икона и иллюстрация религиозной книги сохраняли свою актуальность всегда, то лубок в советский период минимизировал свою представленность в быту старообрядцев разных регионов. Однако в последнее время у некоторых старообрядческих согласий происходит ренессанс настенного листа, который в новых условиях бытования принимает разные специфические формы. 
Особого внимания заслуживает развитие этого феномена у старообрядцев часовенного согласия ${ }^{1}$, проживающих в Енисейской Сибири и поддерживающих связи со своими одноверцами из других регионов страны и мира. Истории этой группы староверов посвящены труды Н. Н. Покровского и Н. Д. Зольниковой (Покровский, 2005; Зольникова, 1996; Покровский, Зольникова, 2002) и других авторов (Татаринцева, Стороженко, 2015), а также сборники доктринальных документов этого согласия (Духовная литература ..., 1999). При этом в большей мере исследованы вопросы, связанные с развитием их литературы (Журавель, 2012) и разных сторон религиозного быта (Казанцева, 2011), в то время как вопросы, связанные с распространением настенного листа, пока остаются практически не изученными. Исследованию классического лубка посвящены работы Е. И. Иткиной (Иткина, 1992), Н. В. Масловой (Маслова, 2015) и др. Современный рисованный настенный старообрядческий лист, в том числе размноженный с помощью новейшей копировальной техники и бытующий у старообрядцев разных регионов, рассматривается в работах Е. И. Плаксиной (Плаксина, 2016), А. В. Кострова (Костров, 2018) и его совместных публикациях с Е. В. Быковой (Костров, Быкова, 2016; Быкова, Костров, 2018) и др.

Приенисенье традиционно является одним из основных регионов расселения часовенных старообрядцев. В среднем течении Енисея в Красноярском крае находится известный духовный центр этого согласия, представляющий из себя несколько скитов (монастырей), которые являются местом притяжения для старообрядцев из разных регионов России (Тувы, Хакассии, Томской, Кемеровской, Свердловской и Иркутской областей, Хабаровского и Приморского краев) и зарубежья. Начиная с 1990-х годов, устойчивые связи с этим конфессиональным центром обретают общины староверов, находящиеся в США (Орегон, Миннесота, Аляска) и в странах Южной Америки (Бразилия, Боливия, Аргентина, Уругвай). Однако после раскола 2013 г., который произошел по поводу возможных вариантов изображения на иконах перстосложения трех нижних пальцев благословящей десницы, символизирующих Троицу, часть староверов, прежде всего староверы из Аляски и Южной Америки, перестали ездить в Дубчесские скиты, так как обители заняли позицию - «не зазирать ('не порицать, не хулить, не осуждать') старые иконы». Проживающие на Урале, в Сибири и на Дальнем Востоке староверы также считают, что «нельзя менять старые иконы» (слова одного из наших информатов из Красноярского края).

Цель статьи - охарактеризовать открытый нами феномен развития визуально-текстовой агиографии в духовном центре и в быту последователей часовенного согласия старообрядчества. В качестве источниковой базы исследования использовались полевые материалы авторов 2016-2018 гг., хранящиеся в личных архивах. Материалы были собраны на территориях в России - в Восточной Сибири (Тува, Красноярский край, Иркутская область) и в США, где находятся общины этого согласия (Орегон, Миннесота). Специфика исследуемого предмета привела к тому, что нами использовались изобразительные, письменные и устные источники. К первой группе относятся портреты духовных лидеров и другие произведения изобразительного искусства современных старообрядцев (настенные листы, иллюстрации рукописей, картины, иконы). Ко второй группе относятся надписи на портретах и духовные стихи (в том числе сопровождающие портреты). К третьей группе относятся интервью, взятые у старообрядцев, проживающих в России и США. При этом наиболее сложными для использования стали именно интервью, так как старообрядцы часовенного согласия традиционно избегают давать информацию о себе и тем более о своих духовных центрах. И если американские информанты иногда позволяли записывать свою речь в тетрадь, то их российские одноверцы совсем не приветствуют ее фиксирование. Поэтому они также, как правило, просят не указывать их данных в публикациях. По этой же причине мы не указываем названия деревень.

\footnotetext{
${ }^{1}$ Последователи этого согласия изначально признавали священство, но в период обострившихся гонений во второй четверти XIX в. перешли к беспоповской практике.
} 


\section{Художественный контекст и истоки появления визуально-текстовой агиографии}

На фоне общего подъема согласия и его духовного центра на Среднем Енисее получила новое развитие своя художественная школа, в которой стали создаваться иконы, картины и разнообразные настенные листы. При этом письменные и литые иконы стилистически ориентируются на классические старинные образцы, хранящиеся в семейных и скитских собраниях, а также опубликованные в современных художественных альбомах («Невьянская икона» и др.).

Картины, выполненные на фигурно оформленных досках, представляют собой романтические виды природы, которые вместе с религиозными текстовыми комментариями, гармонично включенными в изображение, наводят на религиозно-философские размышления. В отличие от иконы подобные картины в конфессиональном искусстве часовенных являются новацией, которая стала занимать свое место в их быту только в последние годы. Это художественное явление говорит об активизации эволюции их культуры, связанной как с возрастанием внешних влияний, так и с новым этапом развития духовного центра. Об этом говорят и создаваемые в скитах настенные листы, которые, с одной стороны, опираются на традиционные лубочные образцы, а с другой, содержат технические, стилистические и жанровые новации.

Среди исторических настенных листов особое место занимают изображения сюжетов и лиц, оказавших заметное влияние на развитие «древлего православия» ${ }^{1}$ Эта традиция своими корнями уходит к классическим лубочным портретам XIX в., таким как «Андрей Денисов», «Никифей Семенов и Семен Титов», которые в наше время были опубликованы Е. И. Иткиной (Иткина, 1992). Бытование новых портретных изображений в традиционном лубочном стиле было зафиксировано нами во время полевых исследований в Верховьях Енисея. Так, в доме пожилой соборной старообрядки были обнаружены современные цветные лубочные портреты древнерусских святых князей Владимира Крестителя и Александра Невского, переснятые с Поморского церковного календаря. Один из этих портретов висел на стене справа от красного угла (мужская сторона), а другой применялся в качестве закладки в постоянно используемой церковной книге.

И все-таки наибольшее внимание художников из часовенных староверов привлекают персоны деятелей своего согласия, которое ими, естественно, понимается как церковь истинная. Одним из самых ярких старых изображений подобного плана является найденное в Орегоне цветное акварельное изображение подконвойного вывоза отца Симеона (в миру Сафона Яковлевича Лаптева) с братией после разгрома Дубчесских скитов в 1951 г. Такой же настенный лист был зафиксирован нами в быту современных обитателей монастырей.

Вот как современные староверы рассказывают об историческом событии, изображенном на этом листе:

«Ну ето в 51-ом году было, када было разорение на старсев. И оне их разорили, все их кельи посожгли, одёжу, книги, всё. У их всё посожгли, поразгоняли, шибко издевалися. Вот иноков связали и на плотах повезли. Скоко-то там проплыли, потом их развязали. А когда солдатыто поуснули, некотры иноки пососкакали. Плот подогнали поближе к берегу и пососкакали, сбежали. Оне сбежали-то, обратно убежали, стали трудиться.

Отес Симеон перед разорением ишо сказал, видать, Богом уже ему сказано было: “К нам придёт красный кот (коммунисты. - А. К., Т. М.), братья. Будьте готовы - нас разорят. Кто помоложе, убегайте, прятайтесь, земли копайте и сидите в землянках, покамест не выглядывайте. И пищу туда несите. Я больще не вернусь. Кое-хто вернётся, а я больше не вернусь. До скончания мира ето место будет здесь. Всё, больше никуда отсуль не разбегайтесь". Так и получилось, а он там так в лагере и умер» (по словам пожилой старообрядки, США).

${ }^{1}$ Так старообрядцы называют дораскольное православие. 
Это изображение скорее всего было создано в 1954 г., перерисовано в 1985 г. и уже с изображения 1985 г. воспроизводилось в последующие годы.

В центре композиции изображен подконвойный вывоз на плотах по реке Дубчес и далее по Енисею арестованных черноризцев и послушников. Автор картины четко показывает слияние двух рек и группу людей, плывущих на плоту. Двое из людей одеты в форму и один из них (по-видимому, известный по этой истории «начальник Софронов») вооружен автоматом (похожим на ППШ) и сидит нога на ногу. Другие люди, одетые в иноческое облачение, сбились в кучу и озираются по сторонам. При этом один из них драматично протягивает руки в сторону реки, из которой они выплыли. Отдельно от всех в позе смирения сидит отец Симеон. Изображенное действие сопровождается надписью: «Оставайтесь горы и леса, уже вы не узрите любимого отца». Таким образом внимание зрителя акцентрируется на главном персонаже этой истории. В достаточно пространном тексте, помещенном ниже изображения, в форме духовного стиха «О разорении скитов» («По Божию велению за грехи моя...») излагается история известного погрома и вывоза в места заключения активного деятеля часовенного согласия старца Симеона и его окружения.

Синтез изображения и текста духовного стиха, посвященного именно этому сюжету, создает специфический и феноменальный жанр визуально-текстовой агиографии. Использование визуальных и текстовых блоков, которые дополняют друг друга, ставит этот феномен между традиционным лубком и лицевой книгой. При этом с точки зрения донесения информационного посыла он гораздо более содержателен, чем лубок, но более прост и доступен, чем книга. И если в книге доминирует текст, а иллюстрации дополняют его визуализацией описанных сюжетов, то в настенном листе наблюдается зеркальная ситуация - доминирует изображение известного сюжета (или персоны), которое дополняется, описывается и комментируется текстом оригинального духовного стиха. Характерно, что приводимый духовный стих не просто имеет отношение к изображенному сюжету - он специально создан для его актуализации в исторической памяти последователей часовенного согласия. Поэтому здесь мы видим союз художника и поэта, а синтезированный из визуального и текстового блоков настенный лист выступает как цельное произведение.

В скитах существует традиция создания духовных мемориальных стихов, которые пишутся в память об усопших уважаемых скитниках («и обязательно какой-нибудь стишок напишут умиленный (милый, сострадательный. - А. К., Т. М.) по человеческой жизни, приблизительно» (слова старообрядки средних лет, США). Сохранение и развитие жанра мемориального духовного стиха могло стать одним из источников формирования визуально-текстовой агиографии на современном этапе. Известно, что многие подобные стихи сочинила одна из послушниц, долгое время проживающая в скиту, известная своим поэтическим талантом и обладающая богатым природным русским языком. При этом подобные стихи могут бытовать как в комплексе с визуальными произведениями, так и в отдельных списках, а также в рукописных сборниках.

В результате эволюции культурной системы лубок и настенный лист подготовили почву и привели к вхождению в религиозный быт часовенных нового для них персонифицированного жанра искусства. В итоге в современную эпоху в скитах получил развитие жанр персонального портрета. И если изображение такого ключевого и драматического сюжета, как погром Дубчеса, требовало многофигурной композиции, то рост индивидуализма и необходимость запечатления духовных лидеров согласия привели к развитию именно индивидуального реалистичного графического портрета. При этом, испытывая на себе влияние традиционных видов изобразительного искусства в виде иконы, книжной иллюстрации, парсуны, классического лубка и настенного листа, он также испытывает влияние светской картины и особенно фотографии. 


\section{Феномен аннотированных портретов духовных лидеров}

Необходимость создания портретов уже ушедших легендарных отцов и матушек советской эпохи привела к использованию их фотографий, взятых из следственных дел первой половины 1950-х годов, часть из которых была опубликована Н. Н. Покровским (Покровский, 2005). То есть в качестве основы визуализации образов духовных лидеров прошлой эпохи были взяты «вынужденные», т. е. следственные фотографии, сделанные не старообрядцами и не для старообрядцев, которые до сих пор настороженно относятся к факту фотографирования.

Примером использования такого фото может быть портретная галерея, размещенная на правой стене моленной ('молельни') одной из старообрядческих деревень Среднего Енисея. Она включает в себя два фотографических изображения (отец Симеон и отец Антоний) и одно рисованное (отец Михаил). Современная эпоха во многом смягчила (но не отменила совсем) запреты, связанные с использованием фотографии, и сделанные ранее снимки стали использоваться даже в религиозном быту часовенных. При этом для общественного пространства, каким выступает храм или трапезная, все еще более предпочтительным считается не фотографический снимок, а рисованный портрет, пусть даже написанный с фотографии, но рукой монаха или монахини в духовном центре согласия. Современные часовенные, использующие «вынужденные» фото своих исторических лидеров (в деревенском, но не в скитском храме), стараются уклониться от греха фотографирования и не принимают «добровольные» фотографии более поздних деятелей, предпочитая им рисованный портрет. Известно также, что часть портретов была написана с натуры, когда «отец сидел, а его рисовали» (слова старообрядки средних лет, США). Сам факт позирования может говорить об эволюции мировоззрения даже самых ортодоксальных часовенных в сторону индивидуализма и осознания своей персональной роли в развитии конфессионального сообщества.

Формирующаяся в скитах художественная школа испытала сильное внешнее влияние, поскольку некоторые инокини до своего ухода в монастырь получили светское художественное образование. Примером тому может служить одна из матушек, которой приписывается авторство более десяти подобных портретов. До своего ухода в монастырь она закончила художественное училище и соответственно принесла с собой знания и навыки современного искусства. Еще одним фактором влияния на либерализацию отношения к использованию фотографии в качестве образца и реалистичного стиля изображения человека стали активные контакты с американскими, прежде всего орегонскими, общинами часовенных.

Под влиянием фотографии и необходимой строгости жанра изображения иноков и инокинь художники применяют монохромную графику с использованием белой плотной бумаги и простого карандаша. Исключением является использование легкого красного тона для обозначения каймы иноческого облачения (мантии и камилавки).

В скитах обычно создается оригинал и несколько копий одного изображения. Одни из них хранятся в обителях, другие посылаются в города и поселки Восточной Сибири (Красноярск, Абакан, Канск, Кызыл, Сарыг-Сеп и др.), а также в штат Орегон, где размножаются с помощью современной компьютерной и полиграфической техники. Часть распечатанных в Орегоне и в других местах «картин» возвращается на Енисей вместе с посылаемой местным старообрядцам милостыней. Кроме того, монахи иногда дарят их паломникам или обменивают на продукты питания («Оне мирянам меняют там на чо-то. Ну хто-то привёз сметану, масло, но они подарят картину. Каждый просит, каждому охота» (слова старообрядки средних лет, США).

Использование цифровых технических средств для копирования и размножения портретов черноризцев говорит о довольно серьезной эволюции ортодоксально настроенной монастырской части часовенных, которые до недавнего времени стремились не принимать в свой быт (и в быт своих последователей) современные технологии.

Показательным примером создания и использования портрета уважаемого скитника является образ отца Григория, годы жизни которого неизвестны. Он был помощником игумена 
(«подигуменом») и пользовался большим уважением. Поэтому после его смерти был создан портрет и написан проникновенный мемориальный стих. Подобный портрет мы видели на стене деревенской избы, в которой живут дальние родственники этого подвижника. Показательно также, что крест о. Григория на скитском кладбище окрашен не в голубой цвет (как у остальных монахов и послушников), а в белый, как у усопших игуменов. Это свидетельствует о высокой степени уважения к нему со стороны скитской братии. Вместе с тем его портрета нет среди портретов игуменов в скитском храме. Таким образом, иерархические правила оказывают влияние на характер бытования портрета религиозного деятеля.

Другим примером бытования визуального образа духовного авторитета часовенных старообрядцев можно отнести обнаруженный нами в молельне одной из таежных деревень Тувы реалистично выполненный графический (карандаш) портрет отца Гурия (Григория Ефремовича Федорова). По рассказам старообрядцев, этот известный своими духовными подвигами черноризец был выходцем из этой деревни, жил и трудился в скитах, а несколько лет назад был задран медведем в лесу во время сбора ягоды («Старушки [так называют в скитах девушек] собирали ягоды, а отес Гурий и ишо один оне были ягоду таскать и как провожатые. Два должны обязательно мужчины быть. И он бежал всё, торопилса: “Скорей, скорей, айдате, старушки, скорей”. И вот одна токо взади его шла. И он как открыл, медведь там спал: “Ох, Миша”, - токо сказал. А медведь-то заорал, его задрал, и всё» (слова старообрядки средних лет, США). По версии других информантов, он был задран во время сбора орехов (например, семья пожилых старообрядцев в Красноярском крае нам сообщила это так: «Задрал медведь на орехах. А он предсказывал до этого, что хорошо быть задранным зверем»).

В память об отце Гурии в скиту был нарисован его портрет и сочинен мемориальный стих. Копия портрета позже была привезена в его родную деревню, где ее поместили на боковой стене правой (мужской) части храма после каноническо-иконографических настенных листов, ближе к двери. После разразившихся в местных общинах споров о допущении вывешивания настенных листов в соборе лубочные изображения убрали, а позже убрали и этот портрет, который был перенесен в дом сестры отца Гурия, где занял почетное место.

Подобное явление наблюдалось и в Орегоне. Вначале настенные листы, привезенные из сибирских скитов, развешали в одном из моленных домов, а потом вынуждены были их убрать («Я их перва развешала в своей серкви. Даже ничо. А потом люди не захотели, зароптали: “Чо мы должны на иконы в серкви смотреть, стоять смотреть, а не картины. Мы молимся не на картины, а на иконы” (слова старообрядки средних лет, США). Однако там портреты духовных лидеров остались на своих местах.

Наряду с фотопортретами основателей Дубчесских скитов отцов Симеона и Антония и графическими изображениями таких уважаемых отцов как о. Григорий и о. Гурий зафиксировано бытование карандашных портретов игуменов скитов: о. Тимофея, о. Лаврентия и о. Михаила. Портрет о. Тимофея висит на внутренней западной стене храма в скиту, который он основал. Рядом с ним висит портрет о. Лаврентия, ставшего игуменом этой обители после него. Портрет о. Лаврентия висит также на западной стене храма в женском скиту, который он окормлял. Более десяти портретов отцов и матушек, в разное время руководивших скитами, составляют своеобразную галерею, развернутую в одном из скитов, и представляют собой визуальный патерик ${ }^{1}$.

Как уже отмечалось, многие из них имеют текстовые дополнения, включающие цитаты изображенных, мемориальные фразы и тексты стихов, посвященные их жизни и уходу. Таким образом формируются визуально-текстовые произведения, развивающие жанр визуальнотекстовой агиографии, в которых надписи и стихи значительно дополняют визуальный образ, придавая ему хронологический простор и драматическую динамику. Статическое изображе-

${ }^{1}$ Патерик - описание истории церкви через биографии ее духовных авторитетов. 
ние религиозного героя обретает в нем свою историю, включающую жизнь, наполненную духовными подвигами и имеющую своим апофеозом уход из нее в жизнь вечную. Именно уход в Царствие небесное стоит в центре внимания старообрядческого поэта, который утверждает праведность жизни настоятеля или наставницы таежных скитов их уходом именно туда, куда должны попадать праведники. Изображенный монах транслируется как идеал, проживший идеальную жизнь (в лишениях, труде и молитве) в идеальном месте (удаленном от грешного мира и его влияния) и согласно христианскому мировоззрению достигший идеальной цели жизни (Царствие небесное). Поэтому в центре произведения - визуальный образ этого идеала при жизни, который обогащен текстологической информацией, развивающей восприятие его причастности к Всевышнему и спасению себя и своих последователей. Это делает его образцом для подражания.

В определенном смысле в этих и других изображениях духовных лидеров часовенных прослеживается развитие традиции бытования лубочного портрета. Потеря в силу утраты священства возможности канонизации благочестивых учителей и - как следствие - невозможность создания их иконных изображений привели к необходимости создания их портретов, сначала лубочных, а потом и реалистичных. На развитие этой традиции оказывала влияние также необходимость ведения родословия своего согласия-церкви ${ }^{1}$, исторически развивающегося в экстремальных условиях гонений и скитаний. Поэтому текстовое родословие согласия, включающее в себя агиографию своих авторитетных учителей, рано или поздно должно было получить свою персональную визуализацию. Уже в имперский период появляются упоминавшиеся лубочные портреты старообрядческих вождей. И если в XX и XXI вв. более либеральные старообрядцы-поповцы (в частности, белокриницкие) ${ }^{2}$ перешли к традиции использования и почитания торжественных фотографий своих архиереев, то часовенные беспоповцы пошли путем создания графических портретов. Последние в иерархии визуальных проявлений старообрядческой культуры заняли следующее место после иконы и иллюстрации религиозной книги. Часовенные старообрядцы не случайно дополнили изображение отточенным и признанным текстом духовного стиха, который, с одной стороны, имеет церковно-фольклорные корни, а с другой стороны, является важным способом передачи своей истории и доктрины.

\section{Графический и поэтический образ известного настоятеля скита отщза Михаила}

Ярким примером этой развивающейся традиции можно считать зафиксированный графический (карандаш) портрет отца Михаила, который сменил отца Антония, бывшего игуменом с начала 1950-х гг. до начала 1970-х гг. Отец Михаил прожил в скитах около семидесяти лет, из них более 40 лет (с начала 1970-х гг. до своего ухода в ноябре 2016 г.) руководил жизнью обители и был очень авторитетным духовным лидером.

Интересно, что перед разорением скитов в 1951 г. $^{3}$ отцу Симеону «пришло извещение от Бога», и он отца Михаила, тогда еще ненакрытого 4 подростка лет 15-17, и еще одного юношу успел отправить в лес, указав направление, и тем самым их спас. Вот как одна из наших информанток (староверка средних лет, США) передает со слов отца Михаила чудесное явление, которое с ними там произошло: «А оне костёр зажгли и глядят - идёт армия к имя. Оне стали молитву творить и к лесинам (деревьям. - А. К., Т. М.) встали, и солдаты возле их мимо прош-

\footnotetext{
${ }^{1}$ Описание преемственности игуменов и других духовных авторитетов, играющее важную роль в исторической памяти старообрядцев часовенного согласия, которые, как и другие старообрядцы, воспринимают своё согласие как церковь.

${ }^{2}$ Старообрядцы, признающие священство и имеющие свою церковную иерархию.

${ }^{3}$ Совершённая в 1951 г. операция властей, направленная на арест и вывоз монахов и послушников скитов.

${ }^{4}$ Послушник до совершения над ним «накрытия» - обряда пострижения в монахи.
} 
ли, как их не видали, а костёр горел». На поясном портрете, созданном, по нашим сведениям, при жизни отца Михаила («Они смотрели на отца Михаила и рисовали» (как сказала пожилая старообрядка, США), он изображен в иноческом облачении (мантия и камилавка) и с лествицей ${ }^{1}$ в руке. В нижней части портрета приведен следующий текст - «Отчины слова: Надо просить Бога, просить и не оставит. Не сможет оставить». Малый вариант такого портрета зафиксирован нами на правой стене молельни одной из старообрядческих деревень Среднего Енисея, где он висит вместе с фотографическими портретами отцов Симеона и Антония.

К обороту картины подклеен листок с текстом мемориального духовного стиха, посвященного уходу и памяти отца Михаила, который, без сомнения, был уважаем и любим монахами и послушниками. Об этом свидетельствует и почтительное обращение к нему (отче, отец, отцем отцов, пустынный пастырь, пастырь верный) и признание большой его заслуги в воспитании в христианском духе молодых староверов (Ты наставлял нас на спасенье, нас, молодых, вере учил, пример нам показал смиренья и о прощеньи говорил). Называется и примерное число иноков и послушников, живущих в скитах (имел ты тысячу овец), на которых распространялось непосредственное влияние этого подвижника.

Текст памятного стиха начинается с указания конкретного времени года (Рассвет зарею загорался, немного снега на земле, месяи ноябрь уж начинался). Далее следует описание предсмертного состояния отца Михаила (Он есть не смог три дня до смерти, вода уж тоже не пошла) и приводится дата его смерти (шестое ноября, в вечерню, оставил отче свой народ).

Очень энергично звучит концовка. Это обращение к отцу Михаилу с просьбой, чтобы тот помолился об иноках перед Господом (Так помолись о нас ты, отче, чтобы грехи нам Бог простил; Подай своею нам молитвой силу в борьбе и на врагов идти смело в любую битву, чтоб не лишил нас Бог венцов).

Представляют интерес некоторые лингвистические наблюдения. Текст духовного стиха, как ему и положено, изобилует церковной лексикой: братия - собир. - 'монахи одного монастыря’, вечерня - ‘богослужение суточного круга, совершаемое вечером' (вечерню братия молилась), грех - 'нарушение действием, словом или мыслью данного Богом нравственного закона, религиозно-нравственных правил, заповедей', сирый - 'осиротевший' (и вот оставил ты нас сирых, нам по грехам ето дано), чадо - 'дети' (в Бога, чадо, верь) и др.

Особенностью стилистики данного духовного стиха является то, что хотя он передается буквами церковнославянского алфавита и в тексте наблюдаются отдельные просодические знаки, он отражает живую разговорную русскую речь, в которой прослеживаются диалектные черты. Автор стиха уже не владеет в полной мере строгими церковнославянскими нормами. Например, наблюдается смешение церковнославянской огласовки и разговорной. С одной стороны, мы наблюдаем отсутствие перехода [е] в ['o] после мягкого согласного, что было свойственно церковнославянскому языку (недугом угнет[е]нный, зар[е]ю), с другой стороны, на месте [е] слышим ['o] (заботой подавл['о]нный), что характерно уже для разговорной речи.

Из диалектных особенностей можно назвать употребление [е] на месте [э]: в [е]тот раз, [е] то дано. Диалектные особенности стиха проявляются также в употреблении глагола щиметь 'ныть, болеть (о сердце, груди и т.п.); щемить' (что-то щимет на душе), наречия смело с наконечным ударением (идти смело в любую битву), в использовании в качестве приглашения или побуждения идти куда-л. междометия айдате («Ну, - айдате, - ты промолвил сквозь хрип, клокочущий в груди») и др.

Прошло совсем немного времени, как упокоился отец Михаил, а в скитах уже появилась литература, посвященная его жизни и смерти («Сколь книг про его уже понаписали: евонно Житье, евонны рассказы, кому чо говорил. Просто удивительно!»).

${ }^{1}$ Старообрядческие глубоко символические четки. 


\section{Духовный стих, посвященный отцу Михаилу}

Рассвет зарею загорался

Немного снега на земле

Месяц ноябрь начинался

Но что-то щимет на душе

Вот снова отче плохо, слышим

Он мучится какой уж год

Но в етот раз труднее дышит

И виден уж конца подход

Он есть не смог три дня до смерти

Вода уж тоже не пошла

Как тяжко слышать нам поверьте

Но весть ужасная пришла

Вечерню братия молились

Был слышен плавный хор певцзов

Когда смиренно покадили

На путь отца, отцем отцов

Плач неутешный, плачи верный

Рыдание утробу рвет

Шестое ноября в вечерню

Оставил отче свой народ

Закрыл глаза, угас светильник

Закрылось солнышко от нас

Лишь только крест, и холм могильный

Мы посещаем каждый раз

Не скажешь отче больше слова

Закрыл уста свои теперь,

А нам так требуется снова

Услышать «В Бога чадо верь»

Ты наставлял нас на спасенье

Нас молодых вере учил

Пример нам показал смиренья

И о прощеньи говорил
Зайдя к тебе с любой тревогой

Как чешуя спадет печаль

И ясно видется дорога

И с легкостью шагаеш в даль

Пустынный пастырь, пастырь верный

Имел ты тысячу овец,

Ихоть недугом угнетённый

О нас болел ты как отец

Последний раз благославляя

Просил нас веру сохранить

На путь спасенья наставляя

Нас о себе просил молить

Тяжелой думой утомленный

Ты не за долго до концза

О нас заботой подавленный

Ночью призвал к себе отиза

Ну «Айдате» - ты промолвил

Сквозь хрип клокочущий в груди

И с Богом только оставайтесь

А мне пора уже пойти

И вот оставил нас ты сирых

Нам по грехам ето дано

Телом ушел ты на могилы

Душа-ж взлетела высоко

Так помолись о нас ты отче

Чтобы грехи нам Бог простил

Мы грешны и унылы очень

Нас просим духом посети

Подай своею нам молитвой

Силу в борьбе и на врагов

Идти смело в любую битву

Чтоб не лишил нас Бог венциов. 
Таким образом, портрет в комплексе с мемориальным стихом является законченным произведением, представляющим собой очень интересный пример визуально-текстовой агиографии современных старообрядцев часовенного согласия.

\section{Заключение}

Показательны локусы, в рамках которых подобный портрет, выполненный в реалистичном стиле и содержащий изображение духовного лидера, реализуется в быту современных часовенных старообрядцев. В частности, зафиксировано бытование в скитах (как в составе галереи, выполняющей функции визуального патерика, так и по отдельности, в том числе на внутренней западной стороне храма), в деревенской молельне (на боковой правой или левой стене в зависимости от пола изображенного), в жилом доме (около красного угла и у изголовья кровати). В любом случае подобное произведение ассоциируется со священным и занимает довольно почетное место, показывающее уровень его почитания. Его помещают возле икон, что позволяет рассматривать этот феномен как дополнительную коммуникацию не только с последователями своего согласия, но и с сакральным, изображенным на иконах.

Подобное обращение к образам и биографиям ключевых персонажей истории согласия подчеркивает и их роль как недавних продолжателей живой традиции стояния за веру, а также характер складывания своей системы авторитетов, как преемственной иерархии личностей, на которых предлагается равняться. И если в литературе часовенных эту функцию выполняют «Родословие часовенного согласия» (Духовная литература ... , 1999: 65-96), «Урало-Сибирский патерик» (там же: 97-158) и некоторые другие произведения, то подобный портретный ряд является их иллюстративным развитием, которое, иконографируя исторические персоналии, вводит их в визуальное измерение культуры старообрядцев. Обогащение портретного образа текстом ключевых фраз и особенно мемориальных духовных стихов превращает его в информативное и драматическое визуально-текстовое агиографическое произведение. В итоге, художественная визуализация агиографической традиции, умноженная смыслами сопутствующих текстов, становится важнейшей частью реконструкции, сохранения и трансляции исторической памяти согласия-церкви.

\section{СПИСОК ЛИТЕРАТУРЫ}

Быкова, Е. В., Костров, А. В. (2018) «Игра пространства» в современном старообрядческом лубке // Научные труды. Вып. 44. январь-март 2018. Проблемы развития отечественного искусства / науч. ред. В. А. Леняшин. СПб.: б./и. 235 с. С. 174-185.

Духовная литература староверов Востока России XVIII-XX вв. (1999) / под ред. Н. Н. Покровского. Новосибирск : Сибирский хронограф. 799 с.

Журавель, О. Д. (2012) Литературное творчество старообрядцев XVIII - начала XXI в.: темы, проблемы, поэтика. Новосибирск: Издательство СО РАН. 442 с.

Зольникова, Н. Д. (1996) Человек и вселенная в сочинениях главы сибирского старообрядческого монастыря о. Симеона // Гуманитарные науки в Сибири. Отечественная история. № 2. C. 50-54.

Иткина, Е. И. (1992) Русский рисованный лубок XVIII - начала XX века. М. : Исторический музей. 256 с.

Казанцева, Т. Г. (2011) Староверы-часовенные Нижнего Енисея: бытовой уклад, литургическая практика, духовно-певческая культура (по материалам полевых исследований) // Материалы X Международной научной конференции «Старообрядчество: история, культура, современность» / отв. редактор В. И. Осипов. М. : б. и. Т. І. 347 с. С. 325-338. 
Костров, А. В. (2018) Историзм в современном настенном листе старообрядцев часовенного согласия // REOSIAHAG. Institute for Russian and Altaic Studies, Chungbuk National Universitu. № 17. P. 229-262.

Костров, А. В., Быкова, Е. В. (2016) «Две дороги - Два пути»: мировоззрение староверовчасовенных в лубочных художественных образах // Res Humanitariae. Vol. 20. Ed. by Rimantas Balsys. Klaipeda University Publishers. C. 58-67.

Маслова, Н. В. (2015) Старообрядческий лубок как наглядная полемика и назидание в вере // Культурное наследие России. № 2. С. 39-45.

Плаксина, Н. Е. (2016) Старообрядческий рисованный лубок на Нижней Печоре: к вопросу о происхождении и бытовании // Декоративное искусство и предметно-пространственная среда. Вестник МГХПА. № 4. С. 235-248.

Покровский, Н. Н. (2005) Путешествие за редкими книгами. Новосибирск : Сова. 344 с.

Покровский, Н. Н., Зольникова, Н. Д. (2002) Староверы-часовенные на востоке России в XVIII-XX вв.: Проблемы творчества и общественного сознания. М. : Памятники исторической мысли. 471 с.

Татаринцева, М. П., Стороженко, А. А. (2015) Старообрядцы Тувы: ретроспектива и современность. Saarbrucken : Lambert Academic Publishing. 137 с.

Дата поступления: 15.11.2018 г.

\section{REFERENCES}

Bykova, E. V., Kostrov, A. V. (2018) «Igra prostranstva» v sovremennom staroobriadcheskom lubke ["The game of space" in the modern Old Believers lubok]. In: Nauchnye trudy. Vol. 44. January - Mars 2018. Problemy razvitiia otechestvennogo iskusstva / ed. by V. A. Leniashin. St. Petersburg, s. n. 235 p. Pp. 174-185. (In Russ.).

Dukhovnaia literatura staroverov Vostoka Rossii XVIII-XX vv. [Spiritual literature of Old Believers of the East of Russia in 18th - 20th centuries] (1999) / ed. by N. N. Pokrovskii. Novosibirsk, Sibirskii khronograf. 799 p. (In Russ.).

Zhuravel', O. D. (2012) Literaturnoe tvorchestvo staroobriadtsev XVIII - nachala XXI v.: temy, problemy, poetika [The literary work of Old Believers from the 18th to early 21st century: issues, problems, poetics]. Novosibirsk, SO RAN Publ. 442 p. (In Russ.).

Zol'nikova,N.D.(1996) Chelovekivselennaiav sochineniiakh glavy sibirskogo staroobriadcheskogo monastyria o. Simeona [Man and the universe in the writings of Fr. Simeon, head of a Siberian Old Belief monastery]. Gumanitarnye nauki v Sibiri. Otechestvennaia istoriia, no. 2, pp. 50-54. (In Russ.).

Itkina, E. I. (1992) Russkii risovannyi lubok XVIII - nachala XX veka [Russian cheap popular print of 18th - early 20th centuries]. Moscow, Istoricheskii muzei. 256 p. (In Russ.).

Kazantseva, T. G. (2011) Starovery-chasovennye Nizhnego Eniseia: bytovoi uklad, liturgicheskaia praktika, dukhovno-pevcheskaia kul'tura (po materialam polevykh issledovanii) [Chasovennye Old Believers of the Lower Yenisei: household style, liturgical practice, church singing culture: from the materials of field research]. In: Materialy XMezhdunarodnoi nauchnoi konferentsii «Staroobriadchestvo: istoriia, kul'tura, sovremennost'» [Materials of 10th international research conference "Old Belief: history, culture, modernity”] / ed. by V. I. Osipov. Moscow, s. n. Vol. I. 347 p. Pp. 325-338. (In Russ.).

Kostrov, A. V. (2018) Istorizm v sovremennom nastennom liste staroobriadtsev chasovennogo soglasiia [Historicism in the modern wall sheets of Old Believers of Chasovennye creed]. REOSIAHAG. Institute for Russian and Altaic Studies, Chungbuk National University, no. 17, pp. 229-262. (In Russ.).

Kostrov, A. V. and Bykova, E. V. (2016) «Dve dorogi - Dva puti»: mirovozzrenie staroverovchasovennykh v lubochnykh khudozhestvennykh obrazakh ["Two roads - Two ways": the world 
picture of the Chasovennye Old Believers in the popular broadsides]. Res Humanitariae, vol. 20. Ed. by Rimantas Balsys. Klaipeda University Publishers. Pp. 58-67. (In Russ.).

Maslova, N. V. (2015) Staroobriadcheskii lubok kak nagliadnaia polemika i nazidanie v vere [Old Believers' lubok (broadside) as a visual controversy and edification in the faith]. Kul'turnoe nasledie Rossii, no. 2, pp. 39-45. (In Russ.).

Plaksina, N. E. (2016) Staroobriadcheskii risovannyi lubok na Nizhnei Pechore: k voprosu o proiskhozhdenii i bytovanii [Old believer hand-drawn lubok of the Lower Pechora: its origin and use]. Dekorativnoe iskusstvo i predmetno-prostranstvennaia sreda, Vestnik MGKhPA, no. 4, pp. 235-248. (In Russ.).

Pokrovskii, N. N. (2005) Puteshestvie za redkimi knigami [A Journey for rare books]. Novosibirsk, Sova. 344 p. (In Russ.).

Pokrovskii, N. N. and Zol'nikova, N.D. (2002) Starovery-chasovennye na vostoke Rossii vXVIII-XX vv.: Problemy tvorchestva i obshchestvennogo soznaniia [Chasovennye Old Believers-chapels in the East of Russia from the 18th to 20th century: problems of creativity and public consciousness]. Moscow, Pamiatniki istoricheskoi mysli. 471 p. (In Russ.).

Tatarintseva, M. P. and Storozhenko, A. A. (2015) Staroobriadtsy Tuvy: retrospektiva i sovremennost' [The old believers of Tuva: a retrospective and modern view]. Saarbrucken, Lambert Academic Publishing. 137 p. (In Russ.).

Submission date: 15.11.2018. 